\title{
Contours of the Future
}

\section{The New Social Dynamics in Cuba}

\author{
by \\ Hans-Jürgen Burchardt
}

The Cuban Revolution of 1959 brought profound economic and social changes. The social structure was homogenized more rapidly than in other socialist experiences (CIPS, 1990), the driving force behind this process being a wide-ranging economic nationalization encompassing 100 percent of the country's commerce industry, finance, and services and 70 percent of its agriculture. This was followed up in the 1970s by a push toward a socialist developmental model that took on many of the features and characteristics of the Soviet experience, especially after Cuba's integration into the world socialist market. The results of this policy were conflicting.

On the one hand, the island recorded sustained economic growth between 1976 and 1985. Important social programs were put in place, and an incomeleveling policy was implemented. In 1989 , for example, the largest salary differential stood at 4.5 to 1 . All this had a strong homogenizing effect on the social sphere. In 1953 the poorest section of Cuban society had accounted for 40 percent of the island's total population but received only 6.5 percent of the island's total direct income. This share jumped to 26 percent in 1986. By contrast, in 1953 the richest section, constituting 10 percent of the population, received 39 percent of total income, but by 1986 this share had dropped to approximately 20 percent (Brundenius and Zimbalist, 1989). Data on the period up to 1989 demonstrate that the main structural features of underdevelopment, especially in the social area, had been eliminated. Social and geographical disparities gave way to significant equality; population growth was balanced. Some 30 percent of the population were active in the country's workforce, 40 percent of which were women. Problems such as malnutrition, unemployment, and massive poverty disappeared.

On the other hand, having taking on many of the features of the Soviet model, Cuba had also assimilated many of its deficiencies. In the course of the 1980s its economic and social development slowed; growth and intensive

Hans-Jürgen Burchardt is an assistant professor in the Institute of Sociology of the University of Hannover. Among his publications are Kuba: Der lange Abschied von einem Mythos (1996), Kuba: Im Herbst des Patriarchen (1999), and, with coeditor Haroldo Dilla, the collection Mercados globales y gobernabilidad local: Retos para la descentralización (2001).

LATIN AMERICAN PERSPECTIVES, Issue 124, Vol. 29 No. 3, May 2002 57-74

C 2002 Latin American Perspectives 
accumulation had reached their limits. In other words, the country had exhausted its social mobility potential; economic stagnation became evident, and the excessive bureaucratic dead weight that had seeped into the different levels of the organization of society became intractable. Consequently, social recognition and upward mobility became linked almost exclusively to administrative and highly qualified professions, while employment in productive activities lost much of its former prestige. This situation was reflected in the growing discrepancy between exigencies and the labor employment structure of the country. One example of this was the high degree of urbanization. Notwithstanding the creation of an agrarian economic base, the agricultural sector ended up developing into an extremely high-cost and import-dependent production structure. Another example was the distortions found in the training of the country's professionals. Between 1980 and 1989 almost half of the university students were graduated as medical doctors or teachers, to the detriment of other technical and professional fields (CEE, 1991).

The dynamic forces propelling the economy also began to falter dangerously. Quantitative growth of the gross domestic product was accompanied by a larger drop in production efficiency (Carranza, Gutiérrez, and Monreal, 1995). This became evident mainly in investments in construction projects, which took an average of 6 months to complete in 1975 and almost 8 years in 1985. Everyone in Cuba knows the story of the nickel-processing plant that has been under construction for over 20 years. The country's energy consumption efficiency also declined. At the end of the 1980s, Cuba's per capita energy consumption placed it fourth in Latin America. In relative figures, this was twice that of the United States and almost triple that of France (Figueras, 1994).

In summary, two endogenous structural elements of the Cuban system condition each other reciprocally and are apparent even today: a form of centralized government controlling everything and the predominance of extensive and inefficient forms of production.

When, at the beginning of the 1990 s, the subsidy flowing in from fraternal socialist assistance was cut off, Cuba lost 75 percent of its foreign trade and, by the same token, its economic base. The former guarantor of Cuba's development-the fundamental economic link with the Soviet Unionturned out, in the end, to be a Janus head, and the Revolution sank into the most acute crisis in its history. The legacy of this experience was an oversized and inefficient economy incapable of surviving without enormous volumes of input and, moreover, specialized in the export of a few raw materials, such as sugar and nickel, and practically estranged from the world market. This abrupt collapse in foreign trade can, therefore, be seen as a first exogenous structural element associated with the transformation. 
To this must be added the effects of the U.S. blockade, which may merit the distinction of being the last institutionalized conflict to have survived the cold war. Notwithstanding the international easing of tensions, the United States has stepped up its confrontation with Cuba. The passage of the HelmsBurton Act in 1996 strengthened the blockade in addition to giving it an extraterritorial dimension. Therefore, the U.S. blockade must be considered as a second exogenous structural element of the Cuban transformation.

\section{THE PARTIAL TRANSFORMATION OF CUBA}

The Cuban leadership responded to the crisis with a partial transformation concentrated only on the economy. Larger reforms in the economic-political areas were vehemently rejected, but attempts have been made since 1992 to rebuild specific sectors of the defunct foreign trade, the aim being the acquisition of hard currency and foreign exchange with the fewest possible concessions. To this end some segments of the economy were selected for "repair" by way of the introduction of market mechanisms, legalization of private property for foreign investors, creation of tax-free economic zones, and various forms of economic association such as mixed enterprises geared toward the world market. The most important economic sectors selected for change were biotechnology, telecommunications, tourism, and prospecting for and extraction of minerals (nickel) and oil. In contrast to these sectors, domestic areas such as manufacturing, agriculture, livestock farming, and the sugar industry continued to deteriorate. No consistent solution to the economic crisis has yet been found. The clearest indication of this is visible in sugar manufacturing, where levels of production have dropped significantly.

The transformation that has taken place can be divided into two stages. In the first, the reform was characterized by a selection strategy aimed at quantitatively broadening the system. In other words, sectors capable of boosting exports were chosen to be adapted to world economic parameters in the hope that they would become enclaves of efficiency without being tied to the rest of economy. The end result was an economic-productive diversification that has been described as a "dual economy" (Burchardt, 1999). In the meantime, sugar production, excluded from the restructuring processes, dropped steadily. The accompanying fall in revenues finally set off a liquidity crisis, and by summer of 1993 Cuba was on the verge of economic collapse.

The government then brought into play an emergency brake, legalizing the use of the U.S. dollar as the country's second currency and, along with that, allowing private holding of foreign exchange. Since then, many of the close to two million Cubans and their descendents living overseas have been 
sending monetary remittances to their relatives on the island. The money flowing into the country in this way provided the basis for a wide-ranging network of state-owned shopping establishments operating in hard currency. Sections of the population were thus able to satisfy an important part of their consumption needs of which they had long been deprived, while the state readily absorbed this new hard-currency cash flow.

This opened up another channel for pulling foreign exchange into the state's coffers and paved the way for a new stage in the process of reforms. This second phase began at the end of 1993 and was characterized, along with a forced export-oriented thrust, by a redefinition of a monetary policy and the implementation of structural microeconomic changes in the country's domestic economy. These measures included radical changes in the agrarian sector (Burchardt, 2001a), liberalizing initiatives in the area of private production, and the introduction of markets. However, these structural changes in the productive base were not accompanied by required transformations at the macro-productive levels. Therefore, this second stage can be described as qualitative but not yet integral and consistent. This does not seem to be the way to overcome the economic crisis. The island, in my view, is in what could be described as a state of "stable stagnation."

In the meantime, however, Cuba can show acceptable social services coverage as well as encouraging results in economic development. During the past five years, Cuba's domestic economy has grown by approximately 20 percent, and this is why Carlos Lage, the man presumably guiding the reforms, has reiterated his assertion that the country's economic recovery is irreversible. Cuba's economy minister has even spoken of a "real miracle." People in the streets in Cuba have, however, appropriated the minister's words and quipped: "So the pope visited the island to learn from Cubans how it's possible to survive on a miracle." With their characteristic keen sense of humor, they point out that so far the economic boom has hardly touched them. With their intuitive skepticism they also, not without reason, distrust overoptimistic forecasts. It is a paradox that the largest source of foreign exchange for the island today is neither sugar nor tourism but private transfers of dollars from overseas, estimated by independent sources to be in excess of US $\$ 800$ 1,000 million. Socialist Cuba's conjunctural recovery is therefore the result of the world's capitalist market and the Cuban exile community. The strategic weakness of this stabilization seems evident. Government sources and foreign observers give no indication of any strategy for integral and consistent reform on the Cuban agenda. The direction of the changes already effected suggests that most of them are the result of tactical and pragmatic thinking, which, moreover, is taking place in a field of tensions between structural conservatism and adjustment pressures. 


\section{THE RETURN OF SOCIAL INEQUALITY}

While economic policies are stagnating, incoherent reforms and the segmentation of the economy have spurred social change. The most obvious such change is the increasing diversification of the social structure. The primary catalyst for this new mobility is the economic discrimination caused by the reforms. Statistics from Cuban economists confirm the impression that income levels are becoming increasingly differentiated. In recent years a significant regrouping of incomes has become apparent. While the number of small savings accounts has dropped by 50 percent, the monetary volume of the most affluent has almost doubled. By the end of 1996,85 percent of all the money deposited in Cuban banks was concentrated in 620,000 private accounts (Beruff, 1997). The funds in these accounts are three times the amount of investments made by the state in 1997. Presumably, most of the cash in circulation is also in the hands of the wealthiest families. This phenomenon is linked, first of all, to the country's need to reintegrate its economy into the international economic system. With the opening up of (albeit still limited) spaces to the market in the area of domestic economic relations, inequality-generating market mechanisms have crept in.

At the onset of the crisis, the government continued to ensure wideranging employment guarantees, rigid rationing of basic supplies, and stable prices for consumer goods, but as production levels dropped most incomes, as well as the availability of goods on the domestic market, shrank noticeably. By 1992 real consumption capacity had declined to one-fourth of average nominal wages. People had more and more money in their hands and nothing to spend it on, and the Cuban peso began to circulate by billions. This dammed-up inflation gave rise to a black market and fueled its growth. In 1993 , close to 60 percent of all the goods in circulation were in the black market, and by 1994 the open inflation rate had increased fiftyfold (Burchardt, 1995; González, 1995). Although the strengthening of the national currency and the introduction of some market options in 1995 contained the more severe impacts of the illegal sector, it remained important. Price increases meant that the average Cuban family would require twice its regular income to satisfy its basic needs (Togores, 2000). Because the austerity policy implemented by the state has considerably reduced real wages for the broad masses, most people can hope to supplement their incomes only via market activities in the informal sector of self-employed workers. Padilla Dieste (1997) estimates that almost 40 percent of the economically active population is involved in some kind of work of this nature.

Herein lies the origin of a central source of social inequality. With the generalization of the self-employed informal sector and the existence of an 
illegal one, a lot of income ceases to depend on social criteria or work efficiency. State transfers of money are devaluated by inflation, and wages lose their former function of social leveling. Living standards come to depend much more on informal networks and privileged activities (such as tourism). The consequence of all this has been a hidden or veiled stratification, together with an asymmetry in income levels.

Another source of social inequality is the legalization of the U.S. dollar as a second currency. Although the government still describes the dollarization of the economy as undesirable, in fact it openly takes advantage of its possibilities. There is an entire new infrastructure for foreign-exchange-based consumption that promises comprehensive gratification. Profits, income opportunities, and consumption preferences are concentrated in this sector. The acquisition of "the enemy's currency" by the local population dominates all of the island's socioeconomic circuits: wealth and status are often based not on work and social functions but on access to the dollar. According to official sources, more than half of the Cuban population enjoys this privilege, although a significantly smaller percentage commands a regular foreignexchange income. Being blessed with the dollar often depends on foreign contacts (remesas), which are mostly family bonds. This implies an arbitrary selection discriminating against two social groups particularly loyal to the system: on the one hand, the Revolution's activists (party members, the military, members of security institutions), who for political reasons have terminated all contacts abroad, and, on the other hand, the former lower stratum of the black Cuban population. Only a small number of black Cubans emigrated from the island, as the Revolution had undoubtedly given them access to improved living conditions. Dollars can also be obtained by working in the foreign-currency section, the "emerging sector" of the economy, but Cuban competitiveness in the world market is mostly limited to low-skilled jobs. Consequently, the revaluing of wages in terms of the U.S. dollar (the dollar/ peso exchange rate fluctuates at around 1:20) eliminated the correlation between professional qualifications and standards of living. Thus, a waiter may earn the monthly salary of a university professor in a single day just through tips. As a result, there is a shift of highly skilled labor to low-skilled jobs that dramatically devalues qualifications and specializations. This fact has had devastating repercussions for the entire social pyramid, the increasing share of highly qualified labor leaving the country being only the tip of the iceberg (Martínez et al., 1996; Urrutia, 1997).

Yet another source of social inequality is the new markets and private production initiatives. These structures are set up in an inconsistent manner and, far from being an incentive to production, are actually a new form of distribution based on a very limited supply of goods and services and a mass of highly 
concentrated consumers. This is the principal reason that there has been no generalization of competitive prices but instead high oligopolic prices favoring further social differentiation. In Cuba today a retiree has to sacrifice his entire monthly pension for two kilos of pork in a farmers' market.

In summary (Espina, 1997: 13-14), income and its sources are playing a strong role in the appearance of social inequalities within and between classes manifested in the strengthening of sources linked to private property, the weakening value of state-sector wages, the appearance on the stage of new groups at the opposite end of the social spectrum, with a significant gap between the enriched and the impoverished, and the presence of groups with high incomes not resulting from their own labor.

\section{SOCIAL STRUCTURES VERSUS SOCIALISM}

Cuba today is characterized by increasing social dynamization and fragmentation. An empirical analysis of incomes makes it is possible to identify the new social groups that came into being on the heels of the economic and existential crisis. Among them are the "new rich" spawned by the black market and illegal activities. Members of this group, benefiting from the crisis, have accumulated large sums of money in bank accounts, stashed away in their homes, or invested in works of arts, jewelry, and the like. Linked with them are certain segments of the new self-employed, private farmers with high incomes, as well as some of the employees in the dollar economy. Those privileged by the reforms include the recipients of foreign-currency remittances, whose number, although there are no official figures available, is estimated to be significant.

This minority of reform winners stands in contrast to the great mass of people left on the margins of the reforms. Within this latter group, on the one hand, are public-service and state employees with low incomes, who in 2002 represented about one-third of the active workforce. To them are to be added poorly paid workers in industry and rural cooperatives, accounting for about half the workforce. The mounting number of unemployed is still more affected by poverty - Cuban economists estimate that underemployment has risen to approximately 30 percent. The looming marginalization is taking place particularly at the social dividing lines of prerevolutionary Cuba. The black Cuban population was especially hard hit by the crisis. The Revolution eliminated institutionalized racial discrimination but without succeeding in sorting out its major internalization effects. Recent Cuban analyses document that "racist stereotypes and prejudices are still present in Cuban society" (Alvarado, 1996: 43) and that they continue to reproduce. A clear sign of 
this subjective discrimination is the limited presence of black Cubans in the political structure, in prestigious positions, and in the dollar sector. As I have mentioned, black Cubans are largely cut off from remittances because of their low levels of migration (Urrutia, 1997). They are even disadvantaged by the liberalization with regard to small private business, which is restricted to private residences and consequently requires space that is more often available to the descendents of the old - white-middle and upper classes. This persistent discrimination harbors the danger of an ethnic restructuring of the social pyramid.

Even the once-harmonious urban-rural relations are giving way to increasing disparity. Internal migration to the capital has risen by leaps and bounds since 1990 and in 1995 for the first time exceeded the prerevolutionary rural exodus. The principal reason is that Cuban farmers today share the fate of many of their Third World counterparts. Through low state-fixed prices for their products, they indirectly subsidize the food supply of the urban population without being able to improve their own standards of living significantly. At the same time, it is not easy to understand why, in spite of the priority accorded by the state to the agricultural sector, even the supply of food is better in the cities than in many areas in the countryside. The concentration of provisions in urban farmers' markets is estimated at 80 percent, with Havana alone accounting for 50 percent (ONE, 2000). Because of agrarian policies that are aggravating working and living conditions in the countryside, the cities, offering profitable and mostly informal income-earning activities, are becoming increasingly attractive. The most deplorable example of the new fortune-hunters of Cuban socialism is the so-called jineteras, prostitutesoften from the countryside- -who offer themselves for quick money to tourists. Thus, the growing developmental disparity between town and country is an additional indicator of social regression in Cuba.

Another aspect of this situation is the increasing corruption. When political cadres are cut off from direct access to foreign currency, corruption is often their response. For example, the involvement of administrative officials in the black market is obvious because it is based principally on the theft and diversion of state property. Other aspects are the decrease in female employment and the increase in crime and public begging.

\section{NATIONAL UNITY AS A STABILIZING FACTOR}

It would be simplistic to conclude from the island's income distribution that we are confronted with the case of a "society divided in two." Income distribution is insufficient to explain Cuba's social structure. For example, a 
Cuban retiree whose pension would place him in the poorest strata can move up to the level of the privileged if he receives monthly remittances from abroad. By the same token, a waitress working in a tourist hotel does not automatically receive the daily blessing of the dollar. At the same time, a tendency toward social polarization must in fact be recognized. How can the stability of Cuban society be accounted for in the face of these centrifugal developments? More specifically, why has Cuban socialism survived the fall of the Berlin Wall and an economic crisis that has lasted more than half a decade? In my opinion, two factors would seem to explain this.

First, social cohesion continues to be significant. It rests on five elements: the principle of social equality; the all-encompassing regulated system of distribution of goods, which-despite its widely discussed harmful falloutstill tends to prevent marginalization; modest material wealth; the integrity of the state; and the historical claim of undivided leadership of the party and Fidel Castro. Nonetheless, although particular elements of this cohesion have broken off and others are in the process of dissolution, the government has avoided the introduction of social decay; until 2002, social transfers amounted to about 40 percent of the budget. Without a doubt, this is the bright side of Cuba's socialism. To it must be added a health care system that in some areas rivals those of the most developed countries. Likewise, the education system continues to guarantee free access to all its institutions, and Cuba remains the only Latin American country in which child labor and illiteracy are unknown. Other elements of the achievements of social cohesion are the pension system, unemployment insurance, and an active employment policy.

These policies stabilized the precarious situation in the labor market and cushioned the social effects of the economic crisis. The potential of this social cohesion-albeit with a connotation of material inequality-can be conceptualized with the help of political sociology, which considers knowledge and social integration as resources-equal to material wealth-for the realization of individual and collective opportunities (Kreckel, 1992; Wilson, 1992). Following this definition, Cuba has neither structural inequality nor its more severe form, social exclusion. Access to knowledge is distributed on an egalitarian basis and broadly socialized. General compulsory school attendance, the health system, the fragmentary public social services, and the promotion of sport and culture prevent social isolation. These public goods tend to equalize an asymmetrical income distribution, prevent the reproduction of social and ethnic selection via the social structure, and, together with state repression, keep the new material inequality from being expressed politically. The commercialization of social relations has so far not provoked a comprehensive dissolution of solidarity and increasing individualization. As a symptom of the crisis we can observe a concentration on exclusive 
reference groups that internally continue to adhere to principles of solidarity but externally function increasingly as economic actors (cf. Fernández, Perera, and Díaz, 1996). The main groups here are the family "as traditional solidarity enclave" (Kreckel, 1992), the neighborhood, and the work collective (work often being conceived as an area in which solidarity was inherent).

The second stabilizing factor is the collective will to preserve national independence. Cuba's "double" colonization (first by Spain and then by the United States) has left marks of oppression on the historical memory of the Cuban population. Because of its defeat of the Batista dictatorship and its persistently adamant position vis-à-vis U.S. aggression, however, the Revolution is the emblem of self-determination. Hitherto only the Castro government has succeeded in integrating this collective historical consciousness into its policies. The government is fully aware of the critical importance of this national independence. Since the 1990s it has therefore promoted nationalism and turned it into a program: at the Fifth Party Congress in 1997 the formerly socialist positions of the party shifted more clearly than ever before in the direction of a radical nationalist doctrine. Party, state, and nation became identical. In addition, Cuban domestic politics in the past few years has been dominated by an invocation of threat scenarios: the external enemy, the United States, is made responsible for all difficulties, and therefore successes can be sold as revolutionary and nationalist acts and presuppose internal unity.

The most vehement expression of this new doctrine was the treatment of the events surrounding the fate of the Cuban boy Elián González. In a massive populist campaign of mobilization in Cuba, all political and honorary leaders in the system were required to demonstrate their loyalty to the government. With this Eliánismo — as some critics ironically termed it - it became possible through subtle appeals to the Cuban sense of family and to national pride to sideline all other topics and demonstrate the persistent threat of the United States to Cuban national sovereignty. This self-styled state of emergency, which became a constant excuse for pleadings for national unity, put all symptoms of crisis on the back burner and muted the debates about solutions. The child's return to Cuba proved the unquestionable role of the Revolution as guardian of its own traditions and independence, which further legitimated its other policies.

Social cohesion and national independence can be summarized as national unity. This can be described as a single collective identity contained by territorial borders whose growth has benefited from social homogenization, collective upward mobility, extensive social security components within the system, high levels of organization and networking, the possibility of geographical exclusion of any opposition or individual dissatisfaction (up to now 
about 10 percent of the population has left the island), the authoritarian-torepressive policies of the state, the ubiquity of its doctrine, and the spatial containment of information because of deficient press freedom and lack of pluralist discourse. This collective identity will be conceptualized here as social and cultural capital. According to political sociology (Bourdieu, 1983; Coleman, 1998; Kreckel, 1992), the capacity for collective reproduction cannot be explained in terms of economic capital alone; other forms of capital must be taken into account. Bourdieu includes social and cultural capital among them and speaks of "incorporated" capital. He understands capital to be a kind of "survival tendency," "an internal force flowing from the objectivity of things" that "can produce profits as well as reproducing itself or growing" (1983: 183). This notion of incorporated capital, which Bourdieu describes as "resources originating in the fact of belonging to a group," helps us to understand the cohesive force of national unity in Cuba.

The function of incorporated capital in creating identity can be observed particularly in the strong nationalism of the former underprivileged. Once again, being economically squeezed by the reforms, these groups demonstrate surprising loyalty to the system. In Cuba, material wealth and the different shades of incorporated capital are interdependent with politics, the economy, and the nation and acquire legitimacy and consolidation synergistically. Following the loss of material stability, the legitimacy of the system could therefore be guaranteed on the basis of incorporated capital and social reproduction. Because of this, I consider national unity the most important stabilizing factor and a third endogenous structural element of the Cuban transformation. Thus, the Cuban brand of socialism basically merges a Leninist state doctrine with an extensive social security system legitimated by the imperative of the defense of national sovereignty. Consequently, Cuba can be understood less in terms of orthodox socialist doctrine than as a radical nationalist regime. Ensuring this national unity, however, not only supports the process of transformation but is the most important source of insecurity.

\section{BLOCKADES AND PROSPECTS FOR A NEW POLICY}

The consequences of this analysis are clear. Bourdieu (1983: 191) identifies "the recognition of a minimum objective homogeneity" as a principal condition for the reproduction of incorporated capital, and one day Cuba's new social inequality must begin to destabilize national unity. Cuba's stability is fragile, and this situation can only be reversed through a new effort at homogenization. But since the reproduction of society has been guaranteed by factors that go beyond mere economics, stability will be achieved not 
on the basis of economic success alone but through political reforms. Therefore, the question of the future for Cuba depends deeply on the further political transformation of the regime.

The charisma of Fidel Castro remains the greatest guarantee of the stability of national unity in Cuba because it prevents fragmentation of the power apparatus. Charismatic rule usually lasts until the death of the charismatic figure, and Castro's pronouncements suggest that he intends to remain in control for life. Thus, he is careful to allow no one to challenge his leadership and promotes a political conservatism that tolerates structural reforms only as a last resort and only in most minimal terms (Mesa-Lago, 1997). However, without deeper political reforms it is likely that a high price will one day be paid for this guarantee. Following this maxim of conservation of power at any price can lead to breakdown: "The actual political regime depends so strongly on the person of Fidel Castro that its future is now more than ever to be identified with his biological longevity. This loss of perspective destroys the ideological basis of the old regime" (Domínguez, 1997: 10). Since the Cuban state apparatus publicly presents itself as a monolith, lacking other charismatic figures, and because there is no established opposition, it becomes extremely difficult to answer the question of political succession in Cuba. Basically, Cuba's political future will depend on which actors with what potentials will be able to prevail. A large role in this scenario will be occupied by the United States and the Cuban exiles living there, but here I will focus on domestic processes.

Most attempts to decipher the current political constellations on the island use the "emerging sector" as their point of departure. Often a political coalition between the technocrats in the dollar sector and parts of the traditional bureaucracy is suspected to guarantee economic stability, societal control, and elite privileges (Dilla, 1999; Habel, 1997). Further analyses even suggest that this technocratic-entrepreneurial group and the influential private entrepreneurs in the informal sector may merge into a new power elite that, as a Cuban bourgeoisie, could become the avant-garde for a capitalist transformation. Without attempting to refute such conjectures, I suggest that there are flaws in this analysis. It would seem that there is an overestimation of the importance of the emerging sector and, conversely, an underrating of the possible resistance of internal political structures. For example, the fact that the dynamics of the selection process within the Cuban Communist Party, with its constant movement of political and economic cadres, have made it difficult for common interest groups to be formed should not be overlooked. At the same time the new rich in Cuba still cannot invest their money productively; capital accumulation continues to be basically an untouchable state monopoly. Nor do they enjoy any opportunity to achieve political influence. 
The state staunchly defends its political omnipotence against the formation of new interest groups.

Therefore, such suspected social constellations are not yet consolidated realities. The character of the Cuban regime makes functionally defined alliances, "subsystems within the system," too risky and dangerous. But it has to be assumed that the agents who benefit from the expansion of the emerging sector and the existence of a dual economy are the ones who are bestorganized and have the greatest potential for self-assertion. Their political arena, which already has the experience of a personalized political culture, would be able to impose its interests via inner circles and form alliances with wealthy foreign and domestic investors. Other actors would first have to learn policy - that is, to constitute themselves and then ally themselves. Their ability to act is unlikely to develop quickly in the context of rapid radical change. In particular, social groups that are discriminated against by the reforms but because of the state's omnipotence have no interest groups to represent them would therefore first have to establish such emancipating organizations. Such a scenario-which appears relatively likely — would cement the economic diversification, accelerate social inequality leading to marginalization and possibly stigmatization of particular groups, impede the growth of a participatory political culture in Cuba, and, consequently, reduce the chances for a civil and socially sustainable transformation. In order to reduce these risks, it will be necessary to introduce political reforms even under the leadership of the current charismatic figure: Cuba's greatest challenge is an incremental democratization of state and society, that is, change autochthonous to the political system and building on that system.

The state's authoritarian character is, however, rooted less in the formal absence of democratic structures than in a political culture that promotes a de facto paralysis of most institutions. Even a change in these processes would initiate a huge democratization and modernization. Some Cuban analysts suggest the following foci for a reform: de-ideologization of the state, decentralization of its administration and a horizontalization of its structures, depersonalization of the system, liberalization of the economy and civil rights, expansion of the rule of law, democratization of the state's search for legitimacy, and some degree of diversification of the media. The Cuban Communist Party is being asked to allow differences within it in order to increase its internal democracy, to make decisions only collectively, and to disallow the occupation of multiple positions (Valdés Paz, 1994; Dilla, 1996a). A central issue for the implementation of such a strategy is the strengthening of the Cuban parliament. For example, the question arises whether Cuba's problems should not be a reason for the highest legislative organ in the country, the National Assembly, to meet more than twice a year. Continuous sessions 
would tend to create a public forum in which current problems could be explained and discussed.

Effective democratization through a liberalization of the party and a strengthening of institutional parliamentarism and the subordinated levels of public administration (Burchardt and Dilla, 2001) would gradually reduce the authoritarian character of the Cuban state and foster political participation. However, a reformed state would have to secure not only its own autonomy but also the independence of other societal systems. It would release religion back into the social sphere and at the same time depoliticize it. It would guarantee the independence of the rule of law and depoliticize it in order to create the conditions for it to operate, and it would draw its legitimacy not from external threat scenarios but from an internal policy of domestic integrative and consensual negotiation. The call for a new policy in Cuba is not necessarily a call for less state but a call for a strong but different state. A new policy does not necessarily mean a dismantling of the centralized state but rather its functional adaptation to decentralized, participatory, and indirect mechanisms of rule.

The increasing heterogeneity of the social structure demonstrates that the Cuban state is no longer able to supply the entire population with its traditional strategies for integration. Instead of leaving the social sphere unoccupied, the government must consciously and publicly endorse and integrate other political actors. In addition to the reform of the state, civil society has to be repoliticized from public tutelage and be granted more space. This argument does not necessarily imply any antagonism between civil society and the state. In principle, it is quite possible for civil society and the state to merge synergetically and provide new legitimacy for the system.

Several intermediary institutions may help to demonstrate this. Private economic initiatives do not necessarily have to be based on private property. They can also emerge from the latest agricultural cooperativization in Cuba, from which about a fifth of the population has come to profit. This model could lead to a broad-based and publicly supported cooperatives culture, creating an economically and politically stable social sector that any future government would have to reckon with (Burchardt, 2000). However, in order to achieve this, the cooperatives would need to be granted the plural interest organizations and forms of articulation that the state has hitherto refused them.

Moreover, there is a need for greater autonomy of Cuban trade unions. The handling of the privatization of industries and the influence labor representatives exert over this process will determine the future political economy of Cuba: they will decide the employment question and, therefore, questions of 
distribution. However, Cuban trade unions still consider themselves a transmission belt for the state and act more like collaborators with management than representatives of labor. It is no surprise, then, that in a representative poll in several state-run companies 61 percent of the workers said that trade unions did not play an important role (Dilla, 1996b). In order to change this, the functions of trade unions have to be redrawn. Trade unions have to divorce themselves from their traditional understanding of politics, recognize different social interests, and transform themselves into advocates of employees' interests instead of supporters of public policy.

Besides the trade unions, the other political mass organizations-which often represent large groups such as women or youth-have to assume a more "civil character." Usually their functions are confined to political instruction rather than seeking practical solutions for the everyday problems of their membership. Thus, according to a Cuban study, the most important wish of almost half of Cuba's young people is improvement of their material conditions. Ten percent each consider the founding of a family, their work, or their avocation most important; political activities are among the last mentioned (Domínguez Garcia, 1994). It is obvious that a youth organization that focuses on political mobilization and ignores the interests of its members is not very attractive. Opening up the mass organizations would therefore mean a diversification of their programs and improved service to their memberships. This would not depoliticize them but begin a repoliticization of their societal basis, which would be able through their social self-organization to find new possibilities for involvement and articulation.

Regarding the possibility for articulation, I offer one final example of Cuba's policy. Civic structures require a sphere for communication if they are to guarantee increasing participation of the political public. Unfortunately, however, the Cuban situation in this regard is a wasteland. The print media, radio, and television have been reduced to almost exclusive dissemination of official government perspectives, which in both style and content are heavily ideological. There is no pluralistic debate. However, the growing international flows of information can no longer be kept from entering the islandthe state's media monopoly is increasingly being undermined and with it the legitimacy of the government. Legitimacy can only be recaptured if the media become again a mirror of the country's reality. This, however, is possible in Cuba's increasingly complex society only if the media have a more pluralistic structure.

The above examples demonstrate that Cuba not only needs a new policy but actually has the resources to build and expand one. Broader political participation via civic structures could help an increasingly heterogeneous 
society to strengthen its capacity for self-regulation. Such networks, initiatives, and overlapping memberships are often able to bridge social lines of conflict and can assist in defusing political crises, mitigating societal conflicts, and, not least, stabilizing the state's ability to act in a crisis. At the same time, however, civil society has to become embedded in strong political institutions. Civil society is not necessarily a civic society-egalitarian, democratic, tolerant, and focused on the common good. It may be aggressive, intolerant, reactionary, antidemocratic, and egoistic (Burchardt, 2001b). Thus, if it is confined to a defense of the autonomous and rational individual without institutional intervention, the -in principle, desirable - reclamation of the citoyen often turns out to be merely an apology for an unbridled "market society." For this reason, the civil society in Cuba's new policy should not be constructed without the state in mind.

The thrust of all these proposals is clear: There is a need to find a new form of governance in Cuba, that is, to reassess the levels of autonomy and interdependence of various actors in the state, market, and society. This is possible only with a strong state and a strong civil society that will basically have to negotiate a new social contract. This social contract will need to attempt not only the restoration of an already brittle consensus but a renewal that would define the nation in terms of agreement rather than in terms of unity. A participatory politics will have to be established in which the reconfiguration and reconstruction of national unity becomes a social project. Meeting this challenge will require not the retention of state socialism but its gradual and fundamental reorganization. As a central objective the state's basis of legitimacy will have to be maintained for the process of gradual transition and subsequent change through negotiation.

Albert O. Hirschman (1995: 168) once observed that modern pluralistic regimes have typically come into being, it is increasingly recognized, not because of some preexisting broad consensus on "basic values" but because various groups that had been at each other's throats for a prolonged period had to recognize their inability to achieve dominance. What was here intended to be a critique of Western democracy can be positively applied to Cuba: The evolution of an alliance for reform need not lead to the same collapse of the system as in Eastern Europe. However, without a new policy Cuba is likely to follow the example of these countries. Therefore, Octavio $\mathrm{Paz}$, reminiscing on the first great social Latin American project of this century, the Mexican Revolution, reminds us where the best prospects for Cuba lie: "Anyone who has seen the hope will never forget it." 


\section{REFERENCES}

Alvarado, Juan Antonio

1996 "Relaciones raciales en Cuba: notas de investigación." Temas, no. 7, 37-43.

Beruff, Alejandro

1997 "Las finanzas internas en Cuba," pp. 10-24 in La economía cubana en 1996:

Resultados, problemas y perspectivas, informe anual del CEEC. Havana.

Bourdieu, Pierre

1983 “Ökonomisches Kapital, kulturelles Kapital, soziales Kapital," pp. 183-198 in R. Kreckel (ed.), Soziale Ungleichheiten. Göttingen: Reinhard Campus-Verlag.

Brundenius, Claes and Andrew Zimbalist

1989 The Cuban Economy: Measurement and Analysis of Socialist Performance. Baltimore: Johns Hopkins University Press.

Burchardt, Hans-Jürgen

1995 “La economía sumergida: ¿De la ilegalidad al programa?" pp. 13-19 in Karl Kohut and Günter Mertins (eds.), Cuba en 1995: Un diálogo entre investigadores alemanes y cubanos. Augsburg.

1999 Kuba: Im Herbst des Partiarchen. Stuttgart: Schmetterling.

2000 La última reforma agraria del siglo. Caracas: Nueva Sociedad.

2001 a "Cuba's agriculture after the new reform: between stagnation and sustainable 'development." "Socialism and Democracy 28: 141-154.

2001 b "La sociedad civil: ¿Indicio de sociedad civilizada o concepto para flemáticos? Una reflexión teórica." Vértice 3-4: 10-15.

Burchardt, Hans-Jürgen and Haroldo Dilla

2001 Mercados globales y gobernabilidad local: Retos para la descentralización. Caracas: Nueva Sociedad.

Carranza, Julio, Luis Gutiérrez, and Pedro Monreal

1995 Cuba-La reestructuración de la economía: Una propuesta para el debate. Havana: Editorial de Ciencias Sociales.

CEE (Comité Estatal de Estadísticas)

1991 Anuario estadístico de Cuba 1989. Havana.

CIPS (Centro de Investigaciones Psicológicas y Sociológicas)

1990 Objetivos sociales y condicionales del desarrollo económico. Havana: Editorial Academica.

Coleman, James S.

1998 "Social capital in the creation of human capital." American Journal of Sociology 94, suppl.: 95-120.

Dilla, Haroldo

1996a "Cuba: la reforma económica, la reestructuración social y la política." Pensamiento Propio 2: 93-105.

1996b "Pensando la alternativa desde la participación." Temas, no. 8, 102-109.

1999 "Comrades and investors: the uncertain transition in Cuba," pp. 227-247 in Leo Panitch and Colin Leys (eds.), The Socialist Register 1999: Global Capitalism versus Democracy. London: Merlin.

Domínguez, Jorge I.

1997 “Comienza una transición hacia el autoritarismo en Cuba?” Encuentro de la Cultura Cubana 6/7: 7-23. 
Domínguez Garcia, Maria I.

1994 "La cultura politica de los jovenes cubanos." MS, CIPS, Havana.

Espina, Mayra

1997 "El espacio para la igualdad." Paper presented to 20th Congress of the Latin American Studies Association, Guadalajara, Mexico, April 17-19.

Fernández, Consuelo, Maricela Perera, and Maiky Díaz

1996 “La vida cotidiana en Cuba: una mirada psicosocial." Temas, no. 7, 92-98.

Figueras, Miguel

1994 Aspectos estructurales de la economía cubana. Havana: Editorial de Ciencias Sociales.

González, Alfredo

1995 "La economía sumergida en Cuba." Cuba: Investigación Económica 2: 77-101.

Habel, Janette

1997 Kuba: Gesellschaft im Übergang. Köln: ISP-Verlag.

Hirschman, Albert $\mathrm{O}$.

1995 Denken gegen die Zukunft: Die Rethorik der Reaktion. München: Suhrkamp.

Kreckel, Reinhard

1992 Politische Soziologie der sozialen Ungleichheit. Frankfurt: Reinhard Campus-Verlag.

Martínez, Milagros, Magaly Martín, Blanca Morejón, Guillermo Milán, Invalis Rodríguez,

Lourdes Urrutia, Consuelo Martín, Antonio Aja, and Marta Díaz

1996 Los balseros cubanos. Havana: Pinos Nuevos.

Mesa-Lago, Carmelo

1997 “Cambio de régimen o cambios en el régimen? Aspectos políticos y económicos.”

Encuentro de la Cultura Cubana 6/7: 36-44.

ONE (Oficina Nacional de Estadísticas)

2000 Ventas en el mercado agropecuario. Havana.

Padilla Dieste, Christina

1997 Nuevas empresas y empresarios en Cuba. Mexico City: FESCARIBE.

Togores, Viviana

2000 "Cuba: los efectos sociales de la crisis y el ajuste económico de los años noventa." Revista de Ciencias Sociales, Universidad de Puerto Rico 8: 106-142.

Urrutia, Lourdes

1997 “Aproximación a un análisis del proceso migratorio cubano.” Papers 52: 49-56.

Valdés Paz, Juan

1994 "La transición socialista en Cuba: continuidad y cambio en los 90," pp. 33-72 in Juan Valdés Paz and Mayra Espina (eds.), La transición socialista en Cuba. Havana: Pinos Nuevos.

Wilson, William Julius

1992 "Public policy research and the truly disadvantaged," pp. 460-481 in Christopher Jencks and Paul E. Peterson (eds.), The Urban Underclass. Washington, DC. 